Journal of Teacher Education for Sustainability, vol. 22, no. 2, pp. 7-25, 2020

\title{
Mapping the Integration of the Sustainable Development Goals in Universities: Is It a Field of Study?
}

\author{
Guillermo Murillo-Vargas, Carlos Hernan Gonzalez-Campo \\ and Diony Ico Brath \\ Universidad del Valle, Cali, Colombia
}

\begin{abstract}
This article maps the scientific production and the contents associated with the sustainable development goals and their integration with universities during the past 21 years. Although many of the topics related to sustainable development goals (SDGs) have been addressed in different studies for decades, it is since 2015 onwards that they gained greater prominence due to the inclusion of higher education as an important actor in the fulfillment of the 2030 agenda and the United Nations SDGs. For the purpose of this paper, a bibliometric analysis of 871 papers, 535 documents in Scopus, and 336 in Web of Science (WoS) from 1998 to 2019 was performed, and the Bibliometrix analysis tool was used. The objective of this mapping is to answer the following research question: Is the integration of the Sustainable Development Goals and Universities a field of study? An analysis of the network of collaborators and trend topics in Scopus and WoS allows us to identify the concurrence and relationships of some keywords, such as sustainable development, sustainability and planning, and some background words, such as humans and global health. In another analysis, the word "higher education" is related to change. This article suggests that the integration of the Sustainable Development Goals in Universities is becoming a field of study under exploration, with a peak of production in 2016 and that has remained stable in the last three years, but thanks to the leading role assigned to Universities, intellectual production should increase in the following years.
\end{abstract}

Key words: sustainable development, objectives, universities, higher education, science mapping

\section{Introduction}

The United Nations Educational, Scientific and Cultural Organization (UNESCO), the UN, the United Nations Development Program (UNDP), and the World Bank (WB), among others, are actors that influence, through their policies and programs, how universities are seen (Beynaghi et al., 2016; Boni \& Walker, 2016). For example, the World Bank has been a notable financier in educational projects, therefore, an important actor 
in the generation of global policies since 1946. However, universities appeared or disappeared as the WB or other organizations decided if they had not complied with the development or established the approach that would be taken by the agendas around education, which sometimes did not include higher education (Boni et al., 2016).

Since the 1970s, environmental education has been part of both political and academic and scientific discourse; however, advances seem to be more rhetorical than real (Sherren, 2006). However, higher education institutions (HEIs) expose their commitment to future generations through curricula with an emphasis on the environment or sustainable development (Cusick, 2009).

At the Cairo Conference held on 5-13 September 1994, the 20-year program of action was approved, which sought to achieve gender equality, improved reproductive health, and stabilization of the population, thus achieving a wide range of sustainable development goals (Maguire, 1998). According to Maguire (1998), the United States Agency for International Development (USAID) has been one of the largest donors in favor of achieving the objectives established in the Cairo Conference. Still, the most relevant aspect is the joint work with universities, which allowed for the generation of specialized knowledge to achieve the respective reproductive health action programs.

On the other hand, Juma (2002), based on little progress in meeting the objectives of the work program of the United Nations Conference on Environment and Development (UNCED) of 1992 in Rio de Janeiro, recognizes the role that universities should play and affirms that they have been underused institutions. However, it is essential to promote sustainable development through professionals with multidisciplinary and ethically oriented training (Moghaddam et al., 2007). In addition, it is necessary to understand the knowledge, attitudes, and practices in different populations to execute a successful transition towards sustainability and not only understand the aspects related to the environment, conservation, ecosystem, natural resources, since human groups are the ones responsible for establishing harmonious relationships with natural systems through a modification of values, beliefs and social behaviors (Salas-Zapata et al., 2018).

The Sustainable Development Goals (SDGs) established in the 2030 Agenda and approved by the United Nations (UN) in September 2015, include for the first time universities to achieve these goals. Consequently, it has been evidenced in various academic documents that it is the first time that higher education is included in the declaration of sustainable development as an important actor. According to Clifford and Zaman (2016), the SDG “challenges the research community to rethink the traditional approach to global health and provides the opportunity for science, technology, engineering, and mathematical (STEM) disciplines, particularly engineering, to demonstrate their benefit to the field". Additionally, universities have gained recognition in recent years from both national and international governments; however, contributions depend on the type of institution (McCowan, 2016).

Based on the above, there has been exponential growth in the production of literature around "ODS", "Higher Education" and "University" since 1998. According to Boni et al. (2016), institutions such as the Organization for Economic Cooperation and Development (OECD), the WB, the UN, and UNESCO, among others, are actors that notably influence the generation of policies at the global level; therefore, they also affect the aspects that are important and unimportant for the achievement of sustainable development goals. Each organization has a different focus; for example, the OECD focuses on 
rich countries, while the WB and the UN focus on developing countries. In this order of ideas, it is interesting to explore through bibliometric indices the literature on the concepts related above.

Zamora-Polo \& Sánchez-Martín (2019) conducted a hermeneutic study that sought to deepen the contribution of HEIs to the promotion of sustainability in the context of the SDGs. The authors argue that HEIs must go beyond the transfer of knowledge, i.e., create new knowledge that helps meet current challenges, which requires a structural change in universities and a change in the vision of teachers. This article demonstrates the change in the focus of research on the SDGs, higher education, and university.

However, documents that focus on the integration of the SDGs in the teaching process or evaluative documents on how higher education can meet and contribute to the objectives of the SDGs or topics related to inclusion predominate. For example, Maruna (2019) verifies the compatibility of the curricula of the study program of the Master's degree in Integrated Urbanism of the Faculty of Architecture of the University of Belgrade with the recommendations of the United Nations, UNESCO and CETP-CEU. Atar \& Rahman (2019) examine the literature on the history and current situation of higher education in Turkey to determine to what extent they have met the sustainable development agenda. Willats et al. (2018) present practical examples of how to integrate the SDGs in the curriculum of HEI outlining the process of integrating the SDGs into the basic curriculum of the Nottingham Trent University (NTU). Najafian and Karamidehkordi (2018) seek to introduce activities and programs of the University of Zanjan to achieve a sustainable campus emphasizing the environment and infrastructure, waste management, water management and education and research.

Ochoa-Duarte and Pena-Reyes (2020) argue that the SDGs are not enough for social development, it is necessary to take into account the local context, for example, Latin America. Salvia et al. (2019) state that in Latin America, the implementation of the SDGs depends on priority of political agendas that compete with the country's main problems. Moreover, the scope of the SDGs becomes complicated when the country's socio-economic conditions are not adequate (Lalama Franco \& Bravo Lalama, 2019), and for this reason, the research addresses issues with the goals of Objective No. 1 "End of poverty" (e.g., Tezanos, 2018). However, research by Lorente Rodríguez (2019) exposes the need to evaluate the problems of the Latin American educational system with the aim of creating plans that successfully affect the achievement of goals established in Objective No. 4 "Quality education".

In short, there is a conceptual and theoretical lack to understand what the university is, what it is for and how it affects society for the achievement of the SDGs (McCowan, 2016). This knowledge is necessary to appease the concern highlighted by Moon et al. (2018) in the XII European Conference on Innovation and Entrepreneurship held in Portugal on 20-21 September 2018, which consists of the impact of HEIs to help achieve the SDGs; the challenges faced by HEIs when integrating the SDGs in the curriculum and institutional strategies; the role of associations for HEIs among students, teachers, government and various stakeholders; and how the adoption of the 2030 Agenda for Sustainable Development, including the SDGs, will transform the work of HEIs and suggest research. 


\section{Historical and Current Context}

Sustainability is a concept that has become increasingly complex; over the years, it tries to address the preservation of natural resources, of human life, the quality of human life and explores practices that allow for continuity that seeks preservation, i.e., future well-being (Amin \& Greenwood, 2018). Therefore, the United Nations Organization promotes a program for educational change, which focuses on the economic, social, and environmental dimensions (The General Assembly, 2015). The educational change began in 1975 when legislative mandates were incorporated into the curriculum of the United Nations International Education Program, which was ratified at the Rio Earth Summit on 14 June 1992, and these actions were supported by Copernicus and the Talloires Declaration (University Leaders for a Sustainable Future) created in 1990 (Iliško et al., 2018). Only in the UN Decade of Education for Sustainable Development (2005-2014) the role of education institutions became clear through the Global Action Program (GAP), in which they established international activities around Education for Sustainable Development (ESD) (Fischer et al., 2015) and in the 2030 Agenda, including for the first time tertiary education or higher education to achieve the objectives (McCowan, 2016).

Education is the key strategy to change the course of our unsustainable dynamics through the 17 United Nations Sustainable Development Goals. Therefore, it is crucial to analyze and reflect on the initiatives adopted and the stakeholders in the initiatives (Jetly \& Singh, 2019), precisely the fourth objective of the SDGs, which focuses on achieving “A Quality Education” (The General Assembly, 2015). In this order of ideas, the 2018 United Nations report identifies teachers as a critical factor, since they, in addition to influencing future professionals, also affect institutional dynamics (Amin \& Greenwood, 2018).

That is, for education institutions, especially universities, to fulfill the role assigned in the 2030 Agenda, to provide quality education, through the strategies established under the framework of ESD, a structural change and a change in teachers' vision, built by understanding what the university is and what it is for (McCowan, 2016; ZamoraPolo \& Sánchez-Martín, 2019) to overcome the challenges demanded by the integration of the SDGs in the curriculum and institutional strategies (Moon et al., 2018). Therefore, the leadership of the directives is a key factor to positively influence the attitude of teachers and students in promoting ESD (Oyetunji, 2011). But, the world's universities require different approaches to address sustainability in their contexts to achieve the 2030 SDGs. For example, higher education in the United States has adequate facilities that address goal 7 "affordable and clean energy", but little impact on the other objectives, especially objective 4 “Quality education” (Smith, 2011), which requires adequate leadership for the integration of the SDGs and to address the lack of clarity of the ESD to incorporate or modify study plans around Sustainable Development, which must contribute notably at the local level and that in parallel respond to global demands for sustainability (Bentham, 2013).

On the other hand, in addition to leadership, teaching and higher education directives require several skills that must go beyond the knowledge of the discipline; it is also necessary to have knowledge and mastery of teaching techniques and methods; in other words, it is essential to promote the professional development of teaching staff (Biasutti 
et al., 2016). This is because "ESD requires interactive teaching and focus on the student" (Ichinose, 2017, p. 36).

According to Dzelzkaleja \& Kapenieks (2018), it is necessary to understand various contradictions that occur in higher education. In other words, it is not only crucial to incorporate ESD, but it is also relevant to implement a systemic approach. The authors have identified seven groups of contradictions (Dzelzkaleja \& Kapenieks, 2018, p. 125):

1. Willingness to teach comprehensively versus availability of financial resources;

2. Traditions versus novelties (in the educational process);

3. Willingness to learn versus willingness to survive economically;

4. Student X versus student Y (different backgrounds, personalities, etc.);

5. "Women's Professions" versus "Men's Professions";

6. The mission of a higher education institution;

7. Skills and knowledge of graduates versus the skills and knowledge needed by the employer.

However, Dzelzkaleja and Kapenieks (2018) agree with Ichinose (2017) that the key to integrating the SDGs is focused on placing the human being at the center.

In the Latin American context, the task is even more complicated since they must overcome the educational backwardness of the $20^{\text {th }}$ century and face the challenges of the $21^{\text {st }}$ century. This situation is due to the inequalities, social, economic, and educational gaps characteristic of the region (Rodríguez, 2019). In the case of Colombia, the SDGs have been gaining space and importance since the 2012 UN Conference on Sustainable Development in Rio de Janeiro, consequently becoming the first country in the world to align the National Development Plan (PND) with the SDGs. However, few goals are related to Higher Education (Pineda-Escobar, 2019).

Finally, it is important to highlight the contributions generated by the Baltic Sea and Black Sea Circle Consortium (BBCC) in the European community around the EDS, which are presented at the annual conferences and whose participatory action research is strongly linked to the activities of UNESCO Chair programs. As mentioned above, change for sustainability is a complex process that involves all stakeholders, especially universities, with lecturers being the key to transformation; therefore, the UNESCO Chair was founded with the reorientation project "Global Teacher Education towards the Goal of Sustainable Development by 2000". It should be noted that the BBCC uses participatory action research to find answers that allow for the reorientation of teacher education towards sustainable development (Pipere et al., 2015; Salite, 2015). Furthermore, the advances of BBCC are evidenced in the remarkable growth of the Journal of Teacher Education for Sustainability in topics such as educational research, research in teacher education, research in sustainability education, and sustainability studies in higher education (Pipere et al., 2015).

\section{Methodology}

There are different methods to analyze the consolidation of a field of study (Bonaccorsi, 2008), with most focusing on a retrospective analysis of intellectual production within a discipline. For Becher and Trowler (2001), the concepts of discipline or field of research are synonymous. While for others such as van den Besselaar and Heimeriks (2006), within a domain, there may be more than one field of study composed of several subfields, 
and these divided into smaller parts that represent different research topics. In this sense, when mapping the integration of the Sustainable Development Goals in universities, a subfield of study is investigated within the field of study of higher education.

Research on the integration of the Sustainable Development Goals in universities follows the bibliometric methodology of scientific mapping. In terms of Cobo et al. (2011), this scientific mapping allows us to construct representations of cognitive structures having as source only the scientific production represented in articles published in scientific journals, for this case, indexed in databases with identification of the level of impact, such as Scopus or Web of Science. This type of scientific mapping has limits, i.e., it does not include other types of institutional documents, such as manuals or institutional publications. As it is a recent topic, since the approval of the SDGs, there are no previous studies of similar mappings for this field or subfield of study.

The role of universities in the sustainable development goals is relatively new (McCowan, 2016). Therefore, through the mapping of information, it is important to identify how concepts such as "university" and "higher education" are involved in sustainable development goals. In this study, we compiled publications from indexed journals included in the databases Scopus and Web of Science (WoS) Core Collection, with the following search parameters: "Sustainable Development Goals" AND university" OR higher education* to locate publications that contained these words in the title, the abstract, author keywords and keywords plus until 2019. A starting year was not included because our intention was to identify from when these topics were included and the trend in the research. In addition, there were no restrictions by type of document. Based on the search parameters, 535 documents were published in Scopus and 336 in WoS. In total, 871 documents were recovered and analyzed in Bibliometrix. Analysis of collaboration networks and the concurrence of the keywords of the existing production were also performed.

\section{Results and Discussion}

The search conducted in the main WoS collection shows that the first document published was in 2013, while in Scopus, it was in 1998. On the other hand, by the type of document, it was identified that the articles in WoS had participation of $88.98 \%$ followed by reviews with participation of $5.35 \%$ and editorials with a percentage of 4.8. In Scopus, the articles have participation of $63.55 \%$; conference documents with $13.08 \%$ take the second place; and book chapters with participation of $10.5 \%$ take the third place (see Table 1).

Regarding the authors, it was identified that a more significant number of authors were concentrated in WoS; therefore, their collaboration index was higher with respect to Scopus. It is an important fact from the perspective of the amount of scientific production.

The behavior of the percentage increase or decrease of publications in both WoS and Scopus is dynamic year after year, with an increase in 2013, 2015, 2016, and a slight increase in 2018 by WoS; then, a decrease is evident until 2019, as shown in Figure 1. 
Table 1

The Main Information of the Search in WoS and Scopus

\begin{tabular}{lcc}
\hline \multicolumn{1}{c}{ Description } & WoS & Scopus \\
\hline Period & $2013-2019$ & $1998-2019$ \\
\hline Sources (magazines, books, etc.) & 197 & 297 \\
\hline Documents & 336 & 535 \\
\hline Average citations by documents & 10 & 5 \\
\hline Average citations per year per document & 3 & 2 \\
\hline References & 15.122 & 23.236 \\
\hline Number of articles & 299 & 340 \\
\hline Number of books & - & 9 \\
\hline Number of book chapters & 1 & 56 \\
\hline Document of procedures & 1 & 70 \\
\hline Number of conference documents & & 1 \\
\hline Number of conference abstracts & - & - \\
\hline Editorial & 16 & 17 \\
\hline Meeting summaries & 1 & 34 \\
\hline Note & - & 1 \\
\hline Abstracts (Review) & 18 & 1.798 \\
\hline Short survey & - & 128 \\
\hline Authors & 2.066 & 1.670 \\
\hline Authors of documents by a single author & 52 & 0.298 \\
\hline Authors of documents by various authors & 2.014 & 3.36 \\
\hline Documents by a single author & 53 & 3.54 \\
\hline Documents by authors & 0.163 & \\
\hline Authors per document & 6.15 & \\
\hline Co-authors per documents & 6.59 & 7.12 \\
\hline Collaboration index & & \\
\hline
\end{tabular}

Source: Bibliometrix data processing and own elaboration.

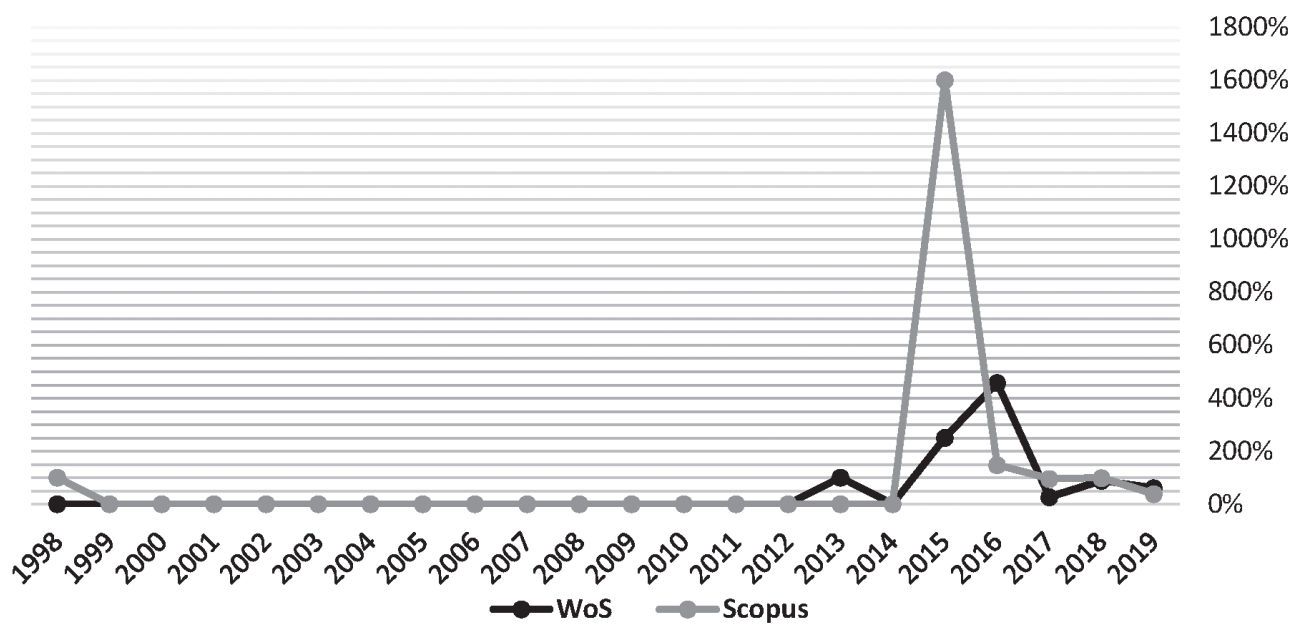

Figure 1. Percentage evolution of publications of Scopus and WoS documents Source: Bibliometrix data processing, elaboration and own calculations. 
On the other hand, the evolution of the number of publications tends to be more homogeneous, but WoS is more dynamic (Figure 2).

In the annual citations per article, WoS stands out with a total average of 13.2 citations, while Scopus has a total average of 7.2 citations. In more detail, the highest level of citations per document in WoS is evidenced in 2016 with a total of 43.6, in 2017 with a total of 10.6 and in 2013 with a total of 9. In Scopus, it is evidenced that in 2009, 13 citations per article were obtained, in 2015 - a total of 11.4 and in 2003 - a total of 11.

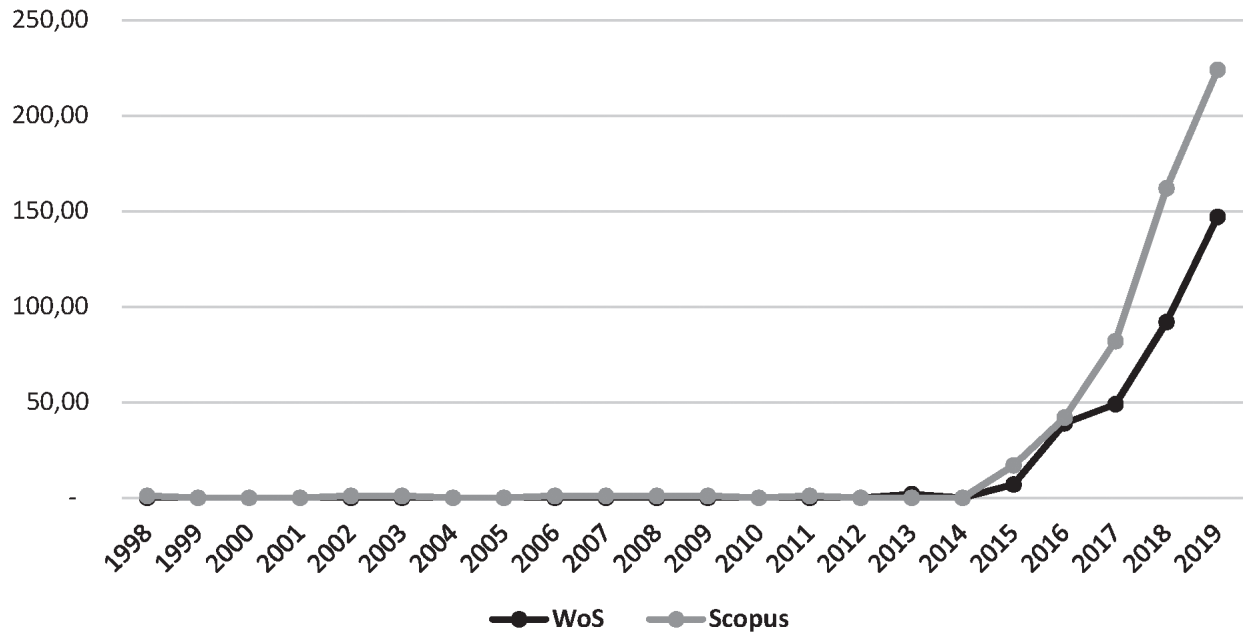

Figure 2. Evolution of publication number of Scopus and WoS documents

Source: Bibliometrix data processing, elaboration and own calculations.

It is observed that journals or publication media with an emphasis on higher education have had an important role in academic production. Magazine such as the International Journal of Sustainability in Higher Education is in the top 10 of both WoS and Scopus, and the International Journal of Management Education ranks ninth in WoS, whose publications began in 2018 and achieved growing importance in the fields of study.

Table 2

Total Citations by Country, Scopus vs. WoS

\begin{tabular}{clclc}
\hline \multirow{2}{*}{ No. } & \multicolumn{2}{c}{ Scopus } & \multicolumn{2}{c}{ WoS } \\
\cline { 2 - 5 } & Country & Total citations & Country & Total citations \\
\hline 1 & United States & 132 & United States & 1265 \\
\hline 2 & Spain & 111 & United Kingdom & 401 \\
\hline 3 & Australia & 105 & Australia & 296 \\
\hline 4 & United Kingdom & 64 & Spain & 252 \\
\hline 5 & South Africa & 46 & South Africa & 216 \\
\hline 6 & Germany & 45 & Germany & 105 \\
\hline 7 & Brazil & 37 & Iran & 90 \\
\hline 8 & Canada & 31 & Cyprus & 73 \\
\hline 9 & France & 28 & Canada & 70 \\
\hline 10 & Japan & 28 & Japan & 42 \\
\hline
\end{tabular}

Source: Bibliometrix data processing, own elaboration. 
The behavior of total citations by country shows that citations are higher in WoS and the behavior of countries varies very little with respect to the positions. However, in the first 10 positions of Scopus, there is a Latin American country, Brazil, while in WoS, the participation of Cyprus, an island located in the Eastern Mediterranean, is observed and Iran takes the seventh position.

When observing the countries by author, the participation of the United States, the United Kingdom, Germany, Spain and Australia in the first five (5) positions predominates in the Scopus database. On the other hand, of the total number of articles by each country, $100 \%$ of the articles of Italy are publications in collaboration with other countries (MCP, Multiple Country Publications); Japan ranks second with $66.7 \%$, and Canada ranks third with $50 \%$. In the case of countries with higher production, work in collaboration with other countries is structured as follows: Australia $37.5 \%$, Germany $33.3 \%$, the United States $26.1 \%$, Spain $22.2 \%$ and the United Kingdom $17.6 \%$, as shown in Figure 3.

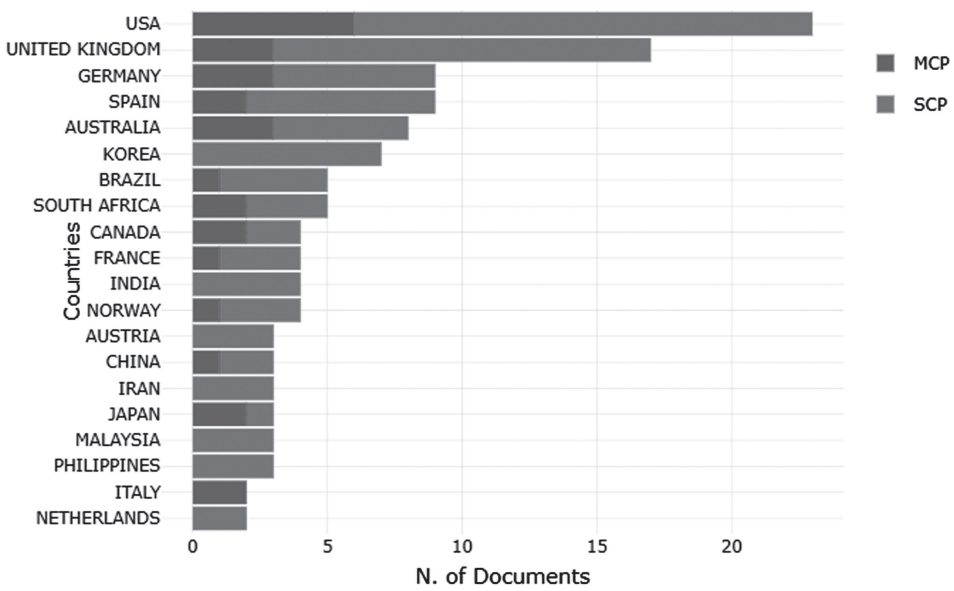

Figure 3. Country of the corresponding author in Scopus

Source: Bibliometrix data processing, own elaboration.

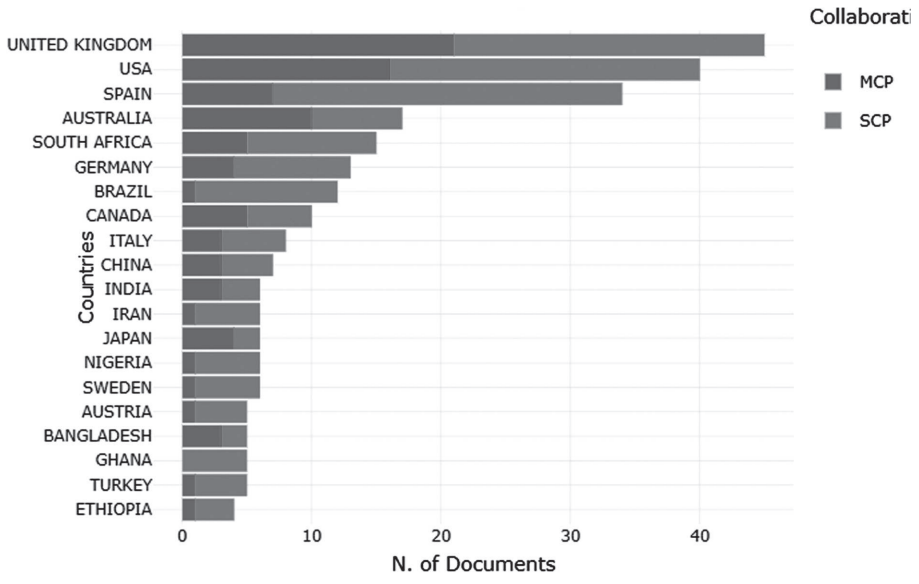

Figure 4. Country of the corresponding author in WoS

Source: Bibliometrix data processing, own elaboration. 
In WoS, it was identified that the United Kingdom had a percentage of collaboration with other countries of $46.7 \%$, the United States - $40 \%$, Spain - $20.6 \%$, Australia $58.8 \%$, South Africa $-33.3 \%$ and Germany $-30.8 \%$. Regarding the country of the corresponding author, the highest percentage of collaboration with other countries was demonstrated by Japan with $66.7 \%$, Bangladesh with $60 \%$, Australia with $58.8 \%$, Canada with $50 \%$ and the United Kingdom with $46.7 \%$, as shown in Figure 4.

The collaboration network in Scopus is led by the United States with connections in France, Italy, India, Indonesia, Norway, the Netherlands, especially with the United Kingdom, which in turn has connections with South Africa, Germany, Switzerland, Ghana, Spain, Nigeria, Brazil, Kenya and as a special connection Australia that has a collaboration network with Canada, China, Japan, the United States, France and Austria. In WoS, the collaboration network is more complex; it is led by the United Kingdom, a country that is related to the United States, South Africa, Germany, Mexico, Nigeria, Spain and Brazil with a strong connection to Australia, which displays a broader collaboration network (see Figure 5). It is worth noting that the most notable collaborations have been mentioned; however, the complexity of collaboration is broader, and the interrelationships are greater.

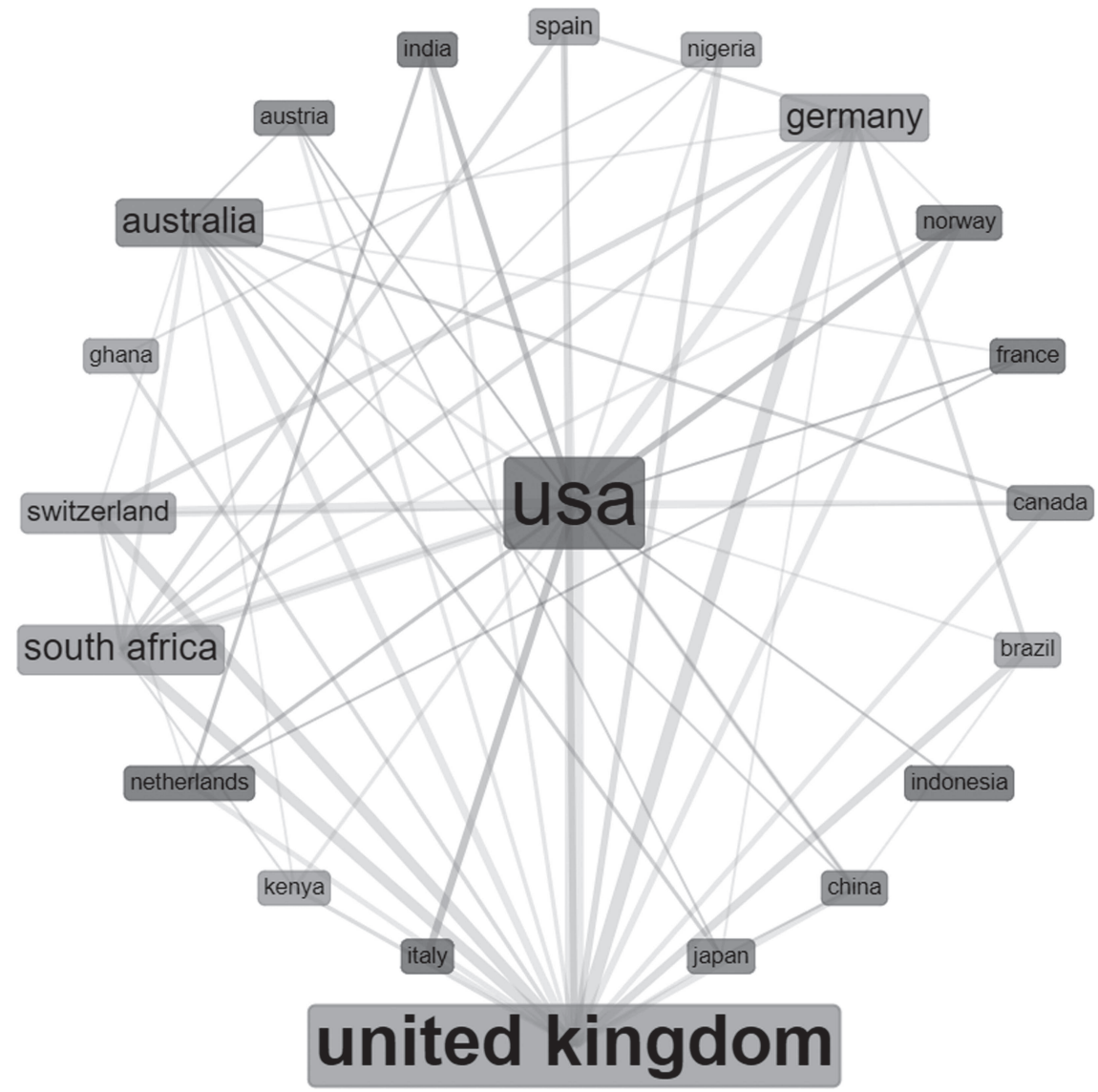

Figure 5. Scopus collaboration network by country 


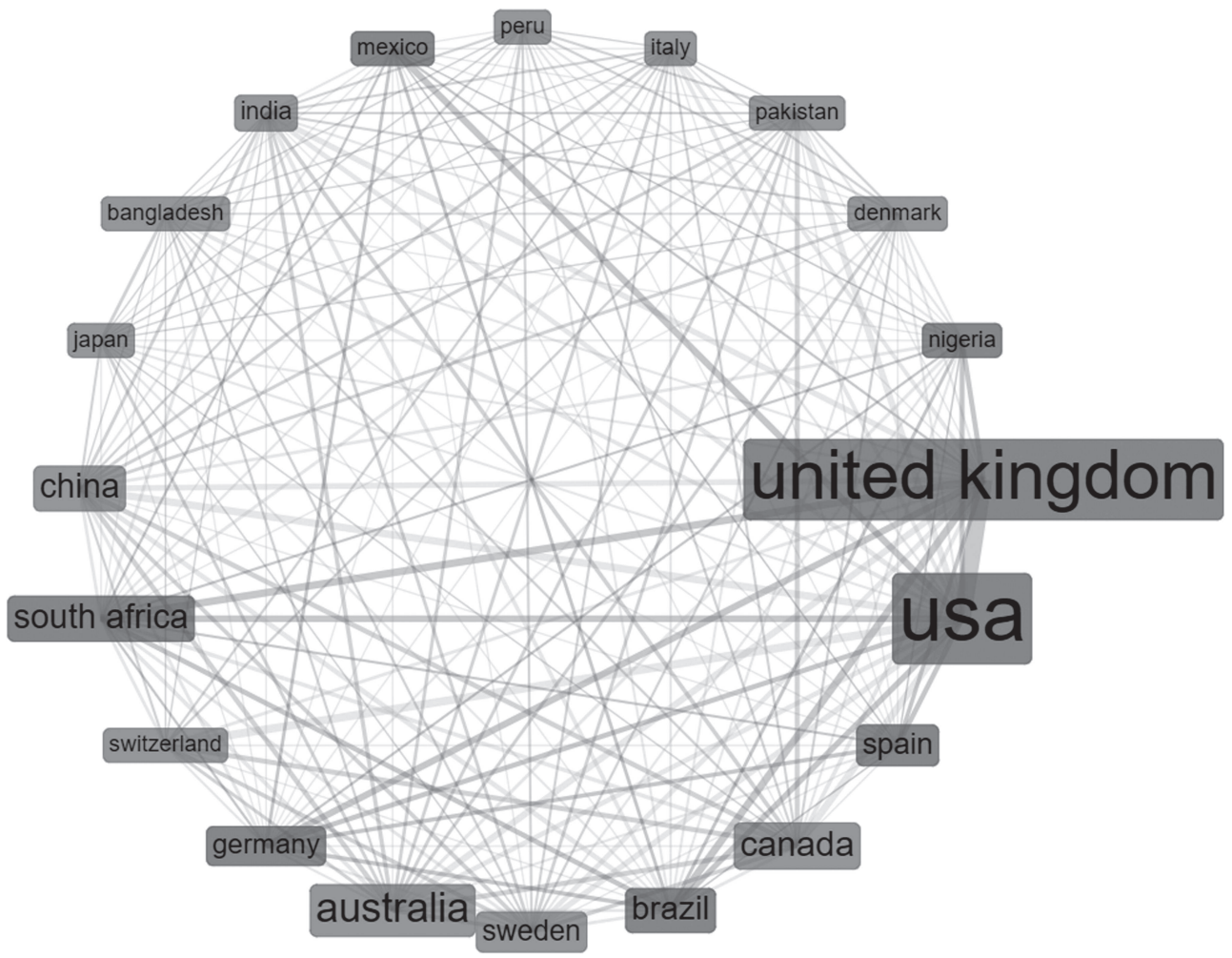

Figure 6. WoS collaboration network by country

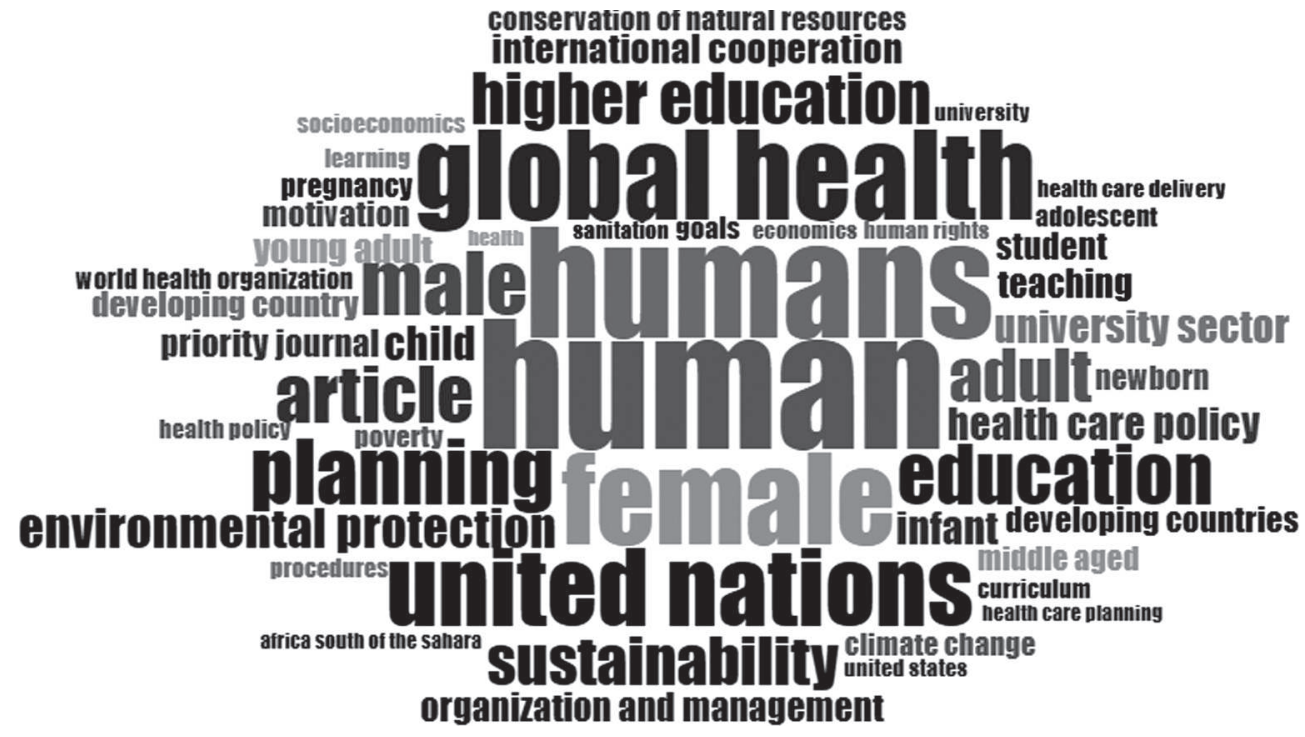

Figure 7. Scopus keywords

Source: Bibliometrix data processing, own elaboration. 


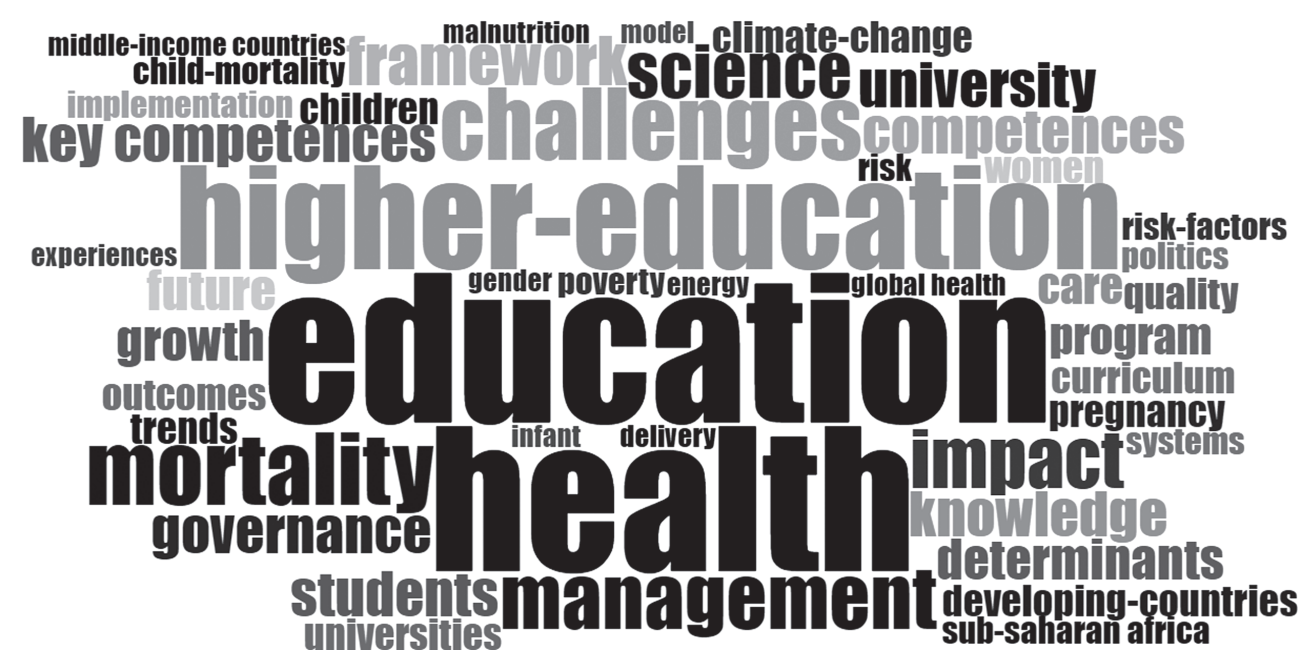

Figure 8. WoS Keywords

Source: Bibliometrix data processing, own elaboration.

To date, notable coincidences have been found between Scopus and WoS; however, the analysis of keywords exposes the following aspects. A total of 781 keywords were identified in WoS and 1962 keywords - in Scopus. The keywords with the highest number of occurrences in Scopus are "sustainable development" (9.2\%), "humans" $(4.7 \%)$, "female" (3.4\%), "global health" (3.3\%), "united nations" $(2.8 \%)$, "planning” $(2.4 \%)$, "male" $(2.3 \%)$, “education" $(2.2 \%)$, “article" $(2.1 \%)$, “adult" $(1.9 \%)$ and "higher education" $(1.9 \%)$, while the words with the highest number of occurrences in WoS are "education" (4.2\%), "health" $(4.1 \%)$, "higher education" $(2.9 \%)$, "challenges" (2\%), "mortality" (2\%), "administration" (1.8\%), "impact" $(1.7 \%)$ "science" $(1.5 \%)$, "framework" (1.4\%) and "competences" (1.3\%).

Table 3

Trend Topics in Scopus and WoS

\begin{tabular}{lcclccc}
\hline \multicolumn{1}{c}{ Stem } & Scopus & & & & Wos & \\
\hline Malnutrition & 9 & 2015 & Mortality & Item & Freq. & Year \\
\hline Austria & 7 & 2015 & Programme & 16 & 2017 \\
\hline Goals & 16 & 2016 & Middle-income countries & 5 & 2017 \\
\hline Human rights & 13 & 2016 & Infant & 5 & 2017 \\
\hline Health & 12 & 2016 & Energy & 5 & 2017 \\
\hline Politics & 11 & 2016 & Health & 32 & 2018 \\
\hline Language & 10 & 2016 & Challenges & 16 & 2018 \\
\hline Environmental protection & 29 & 2017 & Impact & 13 & 2018 \\
\hline Child & 25 & 2017 & Framework & 11 & 2018 \\
\hline International cooperation & 22 & 2017 & Sustainable development goals & 10 & 2018 \\
\hline Motivation & 19 & 2017 & Competences & 10 & 2018 \\
\hline Developing countries & 19 & 2017 & Knowledge & 10 & 2018 \\
\hline
\end{tabular}

See next page for continuation of table 
Continuation of Table 3

\begin{tabular}{lcclcr}
\hline Sustainable development & 177 & 2018 & Governance & 10 & 2018 \\
\hline Human & 93 & 2018 & Education & 33 & 2019 \\
\hline Humans & 80 & 2018 & Higher-education & 23 & 2019 \\
\hline Female & 66 & 2018 & Management & 14 & 2019 \\
\hline Global Health & 65 & 2018 & Science & 12 & 2019 \\
\hline Higher Education & 37 & 2019 & Students & 10 & 2019 \\
\hline Sustainability & 35 & 2019 & University & 10 & 2019 \\
\hline University Sector & 24 & 2019 & Key Competences & 10 & 2019 \\
\hline Teaching & 21 & 2019 & & & \\
\hline Student & 20 & 2019 & & & \\
\hline
\end{tabular}

Source: Bibliometrix data processing, own elaboration.

The trend topic means a trend topic in a specific period. Table 3 demonstrates that in both Scopus and WoS the keywords related to the search terms of this study are concentrated in 2019.

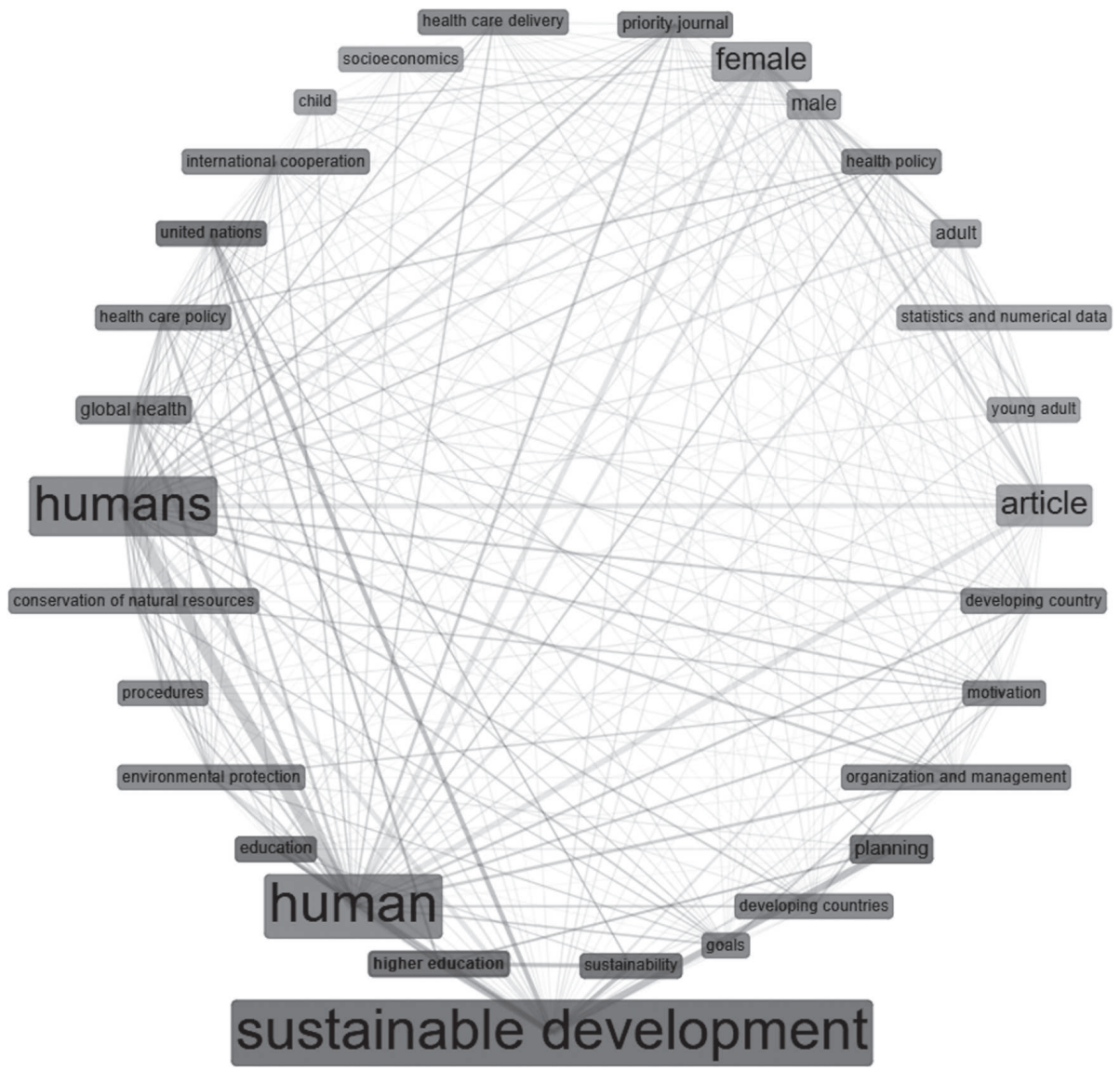

Figure 9. Co-occurrence of the word "higher education" in Scopus

Source: Bibliometrix data processing, own elaboration. 
Co-occurrence occurs when the frequency of $\mathrm{x}$ number of concepts is repeated together; consequently, connections are generated between them. Therefore, in Scopus, it was identified that in the co-occurrence of the word "higher education", it was connected with topics such as sustainable development, sustainability, planning, education and the united nations; in the background with: humans, global health, article, female, male, health policy, developing countries, organization and administration.

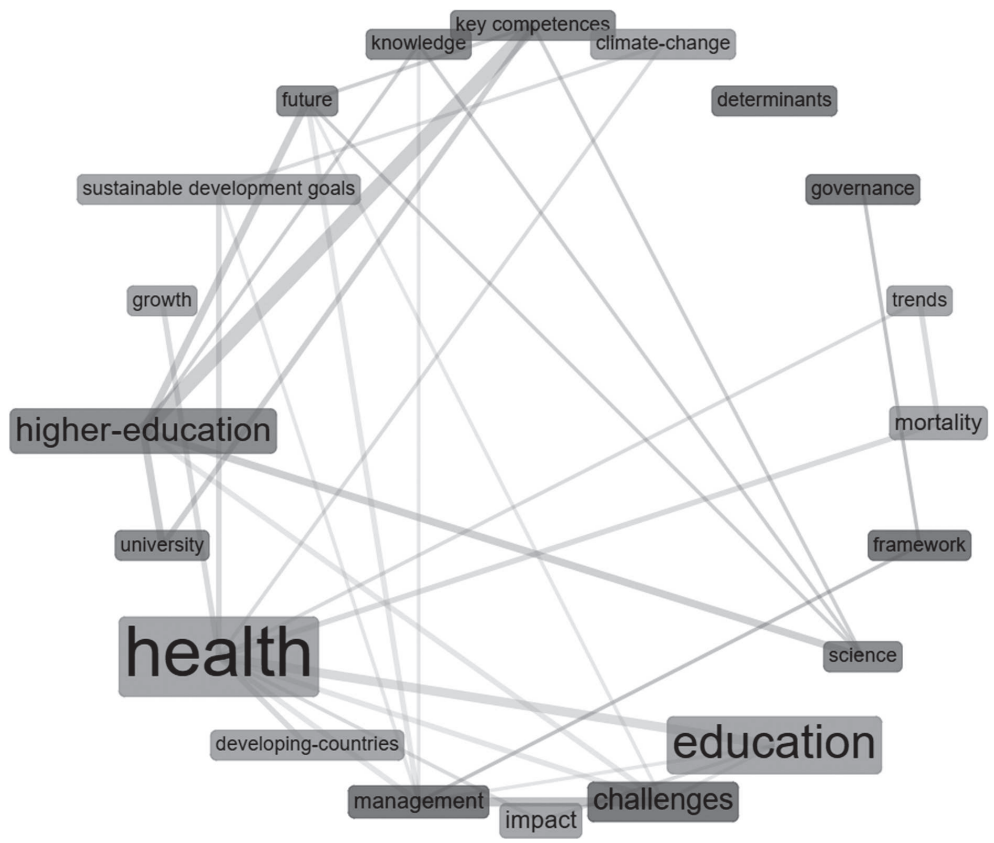

Figure 10. Co-occurrence of the word "higher education" in WoS

Source: Bibliometrix data processing, own elaboration.

In WoS, it was identified that the word "higher education" was closely related to science, knowledge, key competences, future and university; in the background with health, education and administration; finally, a connection with challenges was evident.

\section{Conclusions}

The bibliographic analysis in WoS and Scopus has identified the following. The search window in Scopus is broader, which begins in 1998, while in WoS, it begins in 2003. Additionally, Scopus has a total of 535 documents, while WoS has a total of 336 documents. However, the collaboration index in WoS is 7.12, which is higher than that identified in Scopus, whose collaboration index is 4.13.

Regarding the evolution of publications, there is evidence of a percentage increase in documents published between 2013 and 2018, but their behavior differs between the databases under consideration. In Scopus, there was a significant percentage increase in 2015 , and the publication of documents increased $1600 \%$. In 2016, a slight increase of $147 \%$ was observed compared to the previous year. In 2017, 2018 and 2019, a slight increase of $95 \%, 98 \%$ and $38 \%$, respectively, was observed. In WoS, there was a 
percentage increase of $250 \%$ in $2015,457 \%$ in $2016,26 \%$ in $2017,88 \%$ in 2018 and $60 \%$ in 2019. To sum up, the number of publications is very dynamic in both WoS and Scopus year after year.

When observing the publications from the perspective of the number of documents published, the behavior between Scopus and WoS tends to be homogeneous; however, the trend of the evolution of the number of documents published in Scopus is linear, while in WoS, it exhibits a less regular evolution. This behavior can be justified because the United Nations listed 17 main objectives known as Sustainable Development Goals in 2015 and included higher education as an important actor for the achievement of the objectives, especially those associated with sustainable development and sustainable lifestyles (Bell et al., 2017; McCowan, 2016).

The increase in the number of documents in 2015, 2016 and 2017 led to an increase in citations. The total citations by country in Scopus expose a strong participation of the United States, Spain and Australia and include Brazil as a country of Latin America that ranks seventh. In the case of WoS, the United States, the United Kingdom and Australia are identified with an interesting participation of Cyprus that ranks eighth.

On the other hand, the behavior by the corresponding country in Scopus shows a strong participation of North American authors, and collaboration with authors from other countries has also been found. The same happens with the United Kingdom and Germany, but the nationalities of Korea, India, Austria, Iran, Malaysia, the Philippines and the Netherlands do not show collaboration with others. In WoS, a strong participation of authors from the United Kingdom, the United States and Spain is identified; the three countries present an important collaboration with authors of other nationalities; in general, only Ghana presents authors of single nationality. Therefore, it is evident that the collaboration network is broader in WoS and is led by the United Kingdom, while in Scopus, it is led by the United States.

Keywords are the most relevant aspect in the literature search for information retrieval in a specific study area. It also allows for the identification of research trends, relationships between terms used by the authors and study trends (Gonzalez \& Mattar, 2012). In this order of ideas, it has been observed in Scopus that sustainable development, humans, female and global health are strong topics for document publication, while in WoS, the publication topics are education, health, higher education and challenges. Thus, WoS exhibits more affinity with the study area of the present investigation. When analyzing the trend topic, in both Scopus and WoS, the keywords related to this study are manifested in 2019. The concurrence of words in Scopus details that the word "higher education" has a strong relationship with sustainable development, sustainability, and planning, while WoS states that the word "higher education" is mainly connected with science, knowledge and competences. It is possible to affirm that Scopus focuses on sustainability and the environment and WoS emphasizes the role of education in sustainability.

Finally, in accordance with the objective of this article, after mapping the relationship between the sustainable development goals in universities, it can be considered that we are facing the configuration of a new field of study still to be explored in the coming years, which is evidenced through the level of scientific production. In Scopus and Web of Science, there is an increase in collaboration networks among researchers and research by countries becomes stronger, as well as the level of citations grows year after year. A greater interest in the field of knowledge is associated with the integration of the Sustainable Development Goals in universities. 


\section{References}

Amin, M. A., \& Greenwood, J. (2018). The unsustainable development goals and teacher development for effective English teaching in Bangladesh: A gap that needs bridging. Journal of Teacher Education for Sustainability, 20(2), 118-138. Retrieved from https://doi.org/10.2478/jtes-2018-0019

Atar, C., \& Rahman, S. A. (2019). Higher education in Turkey: Responding to sustainable development agenda. Intellectual Discourse, 27(2), 335-351.

Becher, T., \& Trowler, P. (2001). Academic tribes and territories: Intellectual enquiry and the culture of disciplines ( $2^{\text {nd }}$ ed.). Philadelphia: Open University Press.

Bell, S., Douce, C., Caeiro, S., Teixeira, A., Martín-Aranda, R., \& Otto, D. (2017). Sustainability and distance learning: A diverse European experience? Open Learning, 32(2), 95-102. Retrieved from https://doi.org/10.1080/02680513.2017.1319638

Bentham, H. (2013). Clearing the path that has been laid: A conceptualisation of education for sustainable development. Journal of Teacher Education for Sustainability, 15(2), 25-41. Retrieved from https://doi.org/10.2478/jtes-2013-0009

Beynaghi, A., Trencher, G., Moztarzadeh, F., Mozafari, M., Maknoon, R., \& Leal Filho, W. (2016). Future sustainability scenarios for universities: Moving beyond the United Nations Decade of Education for Sustainable Development. In Elsevier. Retrieved from https://www.sciencedirect.com/science/article/piiS0959652615 015899

Biasutti, M., De Baz, T., \& Alshawa, H. (2016). Assessing the infusion of sustainability principles into university curricula. Journal of Teacher Education for Sustainability, 18(2), 21-40. Retrieved from https://doi.org/10.1515/jtes-2016-0012

Bonaccorsi, A. (2008). Search regimes and the industrial dynamics of science. Minerva, 46(3), 285. Retrieved from https://doi.org/10.1007/s11024-008-9101-3

Boni, A., Lopez-Fogues, A., \& Walker, M. (2016). Higher education and the post-2015 agenda: A contribution from the human development approach. Journal of Global Ethics, 12(1), 17-28. Retrieved from https://doi.org/10.1080/17449626.2016.1148757

Boni, A., \& Walker, M. (2016). Universities and Global Human Development: Theoretical and empirical insights for social change. In Universities and Global Human Development: Theoretical and Empirical Insights for Social Change. Taylor and Francis Inc. Retrieved from https://doi.org/10.4324/9781315742793

Clifford, K. L., \& Zaman, M. H. (2016). Engineering, global health, and inclusive innovation: Focus on partnership, system strengthening, and local impact for SDGs. Global Health Action, 9(1). Retrieved from https:/doi.org/10.3402/gha.v9.30175

Cobo, M. J., López-Herrera, A. G., Herrera-Viedma, E., \& Herrera, F. (2011). An approach for detecting, quantifying, and visualizing the evolution of a research field: A practical application to the fuzzy sets theory field. Journal of Informetrics. Doi: 10.1016/j.joi.2010.10.002

Cusick, J. (2009). Study abroad in support of education for sustainability: A New Zealand case study. Environment, Development and Sustainability, 11(4), 801-813. Retrieved from https://doi.org/10.1007/s10668-008-9144-5

Dzelzkaleja, L., \& Kapenieks, J. Sen. (2018). Contradictions in higher education. Journal of Teacher Education for Sustainability, 20(1), 124-144. Retrieved from https://doi.org/10.2478/jtes-2018-0008 
Fischer, D., Aubrecht, E. L., Brück, M., Ditges, L., Gathen, L., Jahns, M., Petersmann, M., Rau, J., \& Wellmann, C. (2015). UN global action programme and education for sustainable development: A critical appraisal of the evidence base. Discourse and Communication for Sustainable Education, 6(1), 5-20.

González, T. M., \& Mattar, V. S. (2012). Las claves de las palabras clave en los artículos científicos [The keys of the key words in scientific articles]. Revista MVZ Córdoba [Journal MVZ Córdoba], 17(2), 2955-2956.

Ichinose, T. (2017). An analysis of transformation of teaching and learning of Japanese schools that significantly addressed education for sustainable development. Journal of Teacher Education for Sustainability, 19(2), 36-50. Retrieved from https://doi.org/10.1515/jtes-2017-0013

Iliško, D., Oḷehnoviča, E., Ostrovska, I., Akmene, V., \& Salite, I. (2018). Meeting the challenges of ESD competency-based curriculum in a vocational school setting. Discourse and Communication for Sustainable Education, 8(2), 103-113.

Jetly, M., \& Singh, N. (2019). Analytical study based on perspectives of teacher educators in India with respect to education for sustainable development. Journal of Teacher Education for Sustainability, 21(2), 38-55. Retrieved from https://doi.org/10.2478/ jtes-2019-0016

Juma, C. (2002). The global sustainability challenge: From agreement to action. International Journal of Global Environmental Issues, 2(1-2), 1-14. Retrieved from https://doi.org/10.1504/IJGENVI.2002.000985

Lalama Franco, R., \& Bravo Lalama, A. (2019). América Latina y los objetivos de desarrollo sostenible: Análisis de su viabilidad [Latin America and the sustainable development goals: Analysis of its viability]. Revista de Ciencias Sociales [Journal of Social Sciences], 25(NÚMERO ESPECIAL 1 (2019)), 12-24. Retrieved from https://doi.org/10.31876/rcs.v25i1.29591

Maguire, E. (1998). Meeting the challenge of Cairo. Global Issues (Washington, D.C.), 3(2), 20-23. Retrieved from https://www.scopus.com/inward/record.uri? eid=2-s2.00032148870\&partnerID=40\&md5=a31c07620b2016cc45f13d8eb55aac08

Maruna, M. (2019). Toward the integration of SDGs in higher planning education: Insights from integrated urbanism study program in Belgrade. Sustainability (Switzerland), 11(17). Retrieved from https://doi.org/10.3390/su11174519

McCowan, T. (2016). Universities and the post-2015 development agenda: An analytical framework. Higher Education, 72(4), 505-523. Retrieved from https:/doi.org/ 10.1007/s10734-016-0035-7

Moghaddam, M. R. A., Taher-Shamsi, A., \& Maknoun, R. (2007). The role of environmental engineering education in sustainable development in Iran: AUT experience. International Journal of Sustainability in Higher Education, 8(2), 123-130. Retrieved from https://doi.org/10.1108/14676370710726599

Moon, C., Walmsley, A., \& Apostolopoulos, N. (2018). Sustainability and entrepreneurship education. A survey of 307 UN HESI signatories. Proceedings of the European Conference on Innovation and Entrepreneurship, ECIE, September, 2018, 498506.

Najafian, S. M., \& Karamidehkordi, E. (2018). Challenges of sustainability efforts of universities regarding the sustainable development goals: A case study in the University of Zanjan, Iran. E3S Web of Conferences, 48. Retrieved from https://doi.org/10.1051/e3sconf/20184804001 
Ochoa-Duarte, A., \& Pena-Reyes, J. I. (2020). Work in progress: Engineering education for Buen Vivir in the context of $4^{\text {th }}$ industrial revolution. EDUNINE $2020-4^{\text {th }}$ IEEE World Engineering Education Conference: The Challenges of Education in Engineering, Computing and Technology without Exclusions: Innovation in the Era of the Industrial Revolution 4.0, Proceedings. Retrieved from https://doi.org/ 10.1109/EDUNINE48860.2020.9149566

Oyetunji, C. O. (2011). Reorienting leadership styles for sustainable education. Journal of Teacher Education for Sustainability, 13(2), 59-69. Retrieved from https://doi.org/10.2478/v10099-011-0014-0

Pineda-Escobar, M. A. (2019). Moving the 2030 agenda forward: SDG implementation in Colombia. Corporate Governance (Bingley), 19(1), 176-188. Retrieved from https://doi.org/10.1108/CG-11-2017-0268

Pipere, A., Veisson, M., \& Salite, I. (2015). Developing research in teacher education for sustainability: Un DESD via the journal of teacher education for sustainability. Journal of Teacher Education for Sustainability, 17(2), 5-43. Retrieved from https://doi.org/10.1515/jtes-2015-0009

Rodríguez, M. L. (2019). Problemas y limitaciones de la educación en América Latina. Un estudio comparado [Challenges and constraints of the education in Latin America. A comparative analysis]. Foro de Educacion [Education Forum], 17(27), 229-251. Retrieved from https://doi.org/10.14516/fde.645

Salas-Zapata, W. A., Ríos-Osorio, L. A., \& Cardona-Arias, J. A. (2018). Knowledge, attitudes and practices of sustainability: Systematic review 1990-2016. Journal of Teacher Education for Sustainability, 20(1), 46-63. Retrieved from https://doi.org/ 10.2478/jtes-2018-0003

Salite, I. (2015). Searching for sustainability in teacher education and educational research: Experiences from the Baltic and Black Sea Circle Consortium for educational research. Discourse and Communication for Sustainable Education, 6(1), 21-29.

Salvia, A. L., Leal Filho, W., Brandli, L. L., \& Griebeler, J. S. (2019). Assessing research trends related to Sustainable Development Goals: Local and global issues. Journal of Cleaner Production, 208, 841-849. Retrieved from https://doi.org/10.1016/ j.jclepro.2018.09.242

Sherren, K. (2006). Core issues: Reflections on sustainability in Australian University coursework programs. International Journal of Sustainability in Higher Education, 7(4), 400-413. Retrieved from https://doi.org/10.1108/14676370610702208

Smith, G. (2011). Developing a sustainability plan at a large U.S. College of Education. Journal of Teacher Education for Sustainability, 13(2), 5-16. Retrieved from https://doi.org/10.2478/v10099-011-0011-3

Tezanos, S. (2018). Geografía del desarrollo en América Latina y el caribe: Hacia una nueva taxonomía multidimensional de los objet [The geography of development in Latin America and the Caribbean: Towards a new multidimensional taxonomy of the sustainable development goals]. Cepal Review, 2018(125), 7-28. Retrieved from https://doi.org/10.18356/a1fe9e87-en

The General Assembly. (2015). Resolution adopted by the General Assembly on 19 September 2016. A/RES/71/1, 3 October 2016 (The New York Declaration).

van den Besselaar, P., \& Heimeriks, G. (2006). Mapping research topics using wordreference co-occurrences: A method and an exploratory case study. Scientometrics. Doi: 10.1007/s11192-006-0118-9 
Willats, J., Erlandsson, L., Molthan-Hill, P., Dharmasasmita, A., \& Simmons, E. (2018). A university wide approach to embedding the sustainable development goals in the curriculum - a case study from the nottingham trent university's Green academy. In World Sustainability Series. Retrieved from https://doi.org/10.1007/978-3-31970281-0_5

Zamora-Polo, F., \& Sánchez-Martín, J. (2019). Teaching for a better world. Sustainability and Sustainable Development Goals in the construction of a change-maker university. Sustainability (Switzerland), 11(15), 1-15. Retrieved from https://doi.org/10.3390/ su11154224

Correspondence concerning this paper should be addressed to Guillermo MurilloVargas, Professor, Administration and Organizations Department, Universidad del Valle, Sede San Fernando, Calle 4b 36-00 edif. 124 of. 3009, Cali, Colombia. Email: guillermo.murillo@correounivalle.edu.co and

Carlos Hernan Gonzalez-Campo, Professor, Administration and Organizations Department, Universidad del Valle, Sede San Fernando, Calle 4b 36-00 edif. 124 of. 3012, Cali, Colombia. Email: carlosh.gonzalez@correounivalle.edu.co 